\title{
Drought Responses among Seven Southwestern Landscape Tree Taxa
}

\author{
Coye A. Balok ${ }^{1}$ and Rolston St. Hilaire ${ }^{2}$ \\ Department of Agronomy and Horticulture, New Mexico State University, Box 30003, Las Cruces, NM \\ 88003
}

ADDITIONAL INDEX wORDS. cuticular wax, Fraxinus velutina, Koelreuteria paniculata, leaf morphology, oaks, Quercus sp., water potential

\begin{abstract}
Identification of tree taxa that can thrive on reduced moisture regimes mandated by xeriscape programs of the southwest United States could be facilitated if responses to drought of those taxa are determined. Leaf water relations, plant development, and cuticular wax content of seven taxa maintained as well-irrigated controls or exposed to drought and irrigated based on evapotranspiration were studied. Leaf water potential of drought-stressed Fraxinus velutina Torr. (Arizona ash), Koelreuteria paniculata Laxm. (golden rain tree), Quercus macrocarpa Michx. (bur oak), and Quercus muehlenbergii Engelm. (chinkapin oak) were lower at predawn than the controls. Drought-stressed plants of $F$. velutina, K. paniculata, and Quercus lobata Née (California white oak) had more negative midday water potential than the control plants. Drought reduced stomatal conductance to as little as $17 \%, 23 \%$, and $45 \%$ of controls in $F$. velutina, K. paniculata, and $Q$. macrocarpa, respectively. Drought-stressed plants of $F$. velutina, K. paniculata, $Q$. macrocarpa, and $Q$. muehlenbergii had reduced transpiration rates. Fraxinus velutina had both the highest net assimilation rate (NAR) and relative growth rate (RGR) regardless of irrigation treatment. Mean specific leaf weight (dry weight (DW) of a 1-cm² leaf disc divided by the weight), trichome density, stomatal density, leaf thickness, and cuticular wax content varied among species but not between irrigation treatments. Leaves of $Q$. buckleyi Buckl. (Texas red oak) had one of the highest stomatal densities, and also had leaves which were among the waxiest, most dense, and thickest. Abaxial leaf surfaces of $F$. velutina were the most pubescent. Across species, drought led to lower ratios of leaf surface area to root DW, and leaf DW to root DW. Quercus buckleyi plants subjected to drought had the highest root to shoot DW ratio (3.1). The low relative growth rate of $Q$. buckleyi might limit widespread landscape use. However, $Q$. buckleyi may merit increased use in landscapes on a reduced moisture budget because of foliar traits, carbon allocation patterns, and the relative lack of impact of drought on plant tissue water relations.
\end{abstract}

Limited water supplies, increasing water prices, and urbanization have prompted municipalities in the arid southwestern United States to implement xeriscape programs (Smith and St. Hilaire, 1999). As municipalities continue to expand xeriscape programs, more information is needed on plants with the capability to thrive on reduced moisture regimes mandated by those programs (Nash and Graves, 1993). Landscape personnel are interested in using a greater variety of plants in xeriscapes, but performance of these plants in those landscapes is not well understood. Furthermore, plant water deficit stress, already common in the southwestern United States may be exacerbated by pavement and compacted soils that reduce infiltration of precipitation into root zones (Whitlow and Bassuk, 1988).

Several studies have evaluated water use of plants used in southwestern landscapes (Devitt et al., 1995; Feldman et al., 1997; Levitt et al., 1995), but Tipton (1994) cautioned that the capacity of landscape plants to survive drought can be more significant in determining plant survival than their ability to use water efficiently. Tipton (1994) showed that Chilopsis linearis (Cav.) Sweet (desert willow), indigenous to the Southwest, was more resistant to drought than the nonindigenous Tecoma stans (L.) Juss. ex HBK (yellow bells) and Morus alba L. (mulberry). Hamerlynck and Knapp (1996) found that the purportedly droughttolerant Quercus muehlenbergii (chinkapin oak) seasonally reduced osmotic potential and had lower stomatal conductances than the purportedly less drought-tolerant $Q$. macrocarpa (bur

Received for publication 23 Mar. 2001. Accepted for publication 24 Oct. 2001. Contribution of the New Mexico Agricultural Experiment Station, New Mexico State University, Las Cruces. Use of trade names does not imply endorsement of the products named nor criticism of similar ones not named.

${ }^{1}$ Former graduate student.

${ }^{2}$ Assistant professor and corresponding author; e-mail rsthilai@nmsu.edu. oak). Thus, more information is needed on the tolerance to drought of plants for use in southwestern landscapes.

Plants have developed several morphological, anatomical, and physiological traits for responding to and resisting drought (Augé et al., 1998). Foliar morphology is a quick way to assess the impact of drought on plants (Kubiske et al., 1996). In several plant taxa, drought reduces leaf surface area (Kriedman, 1986; Roden et al., 1990), but intrinsic morphological traits such as pubescence (Schuepp, 1993; St. Hilaire and Graves, 1999, 2001), thick leaves, and leaf cuticular waxes (Tipton and White, 1995) could temper the effects of drought. Leaf cuticular waxes reduce nonstomatal water loss and the diffusion of solutes across the cuticle (Post-Beittenmiller, 1996; Riederer and Schneider, 1990). Drought may also alter stomatal conductance (Fort et al., 1997), plant biomass partitioning (Graves and Wilkins, 1991), and leaf water potential (Augé et al., 1998).

The objective of this research was to characterize and compare responses to drought of seven plant taxa that could be used in southwestern xeriscapes. Because plants exhibit a continuous range of responses to drought (Augé et al., 1998), we focused on variations in leaf water relations and plant morphological, anatomical, physiological, and developmental traits that may represent drought tolerance mechanisms.

\section{Materials and Methods}

Plant Material. Three-year-old, dormant seedlings of $Q$. buckleyi (Texas red oak), Q. lobata (California white oak), $Q$. macrocarpa (bur oak), Q. muehlenbergii (chinkapin oak) and $Q$. shumardii Buckl. (Shumard oak) were obtained from Trees That Please, Los Lunas, N.M. and potted 27 Feb. 1999. Seeds of $Q$. buckleyi originated from the Glass Mountains (lat. 30 53'38"N; 
long. $102^{\circ} 52^{\prime} 44^{\prime \prime} \mathrm{W}$ ) in west Texas. Seeds of $Q$. lobata and $Q$. shumardii were collected from arboretum trees in Los Lunas, N.M. (lat. $34^{\circ} 48^{\prime} 18^{\prime \prime N}$; long. $106^{\circ} 43^{\prime} 42^{\prime \prime W}$ ). Seeds of $Q$. macrocarpa were collected $16 \mathrm{~km}$ east of Caprock, N.M. (lat. $33^{\circ} 23^{\prime} 30^{\prime \prime N}$; long. $\left.102^{\circ} 42^{\prime} 36^{\prime \prime} \mathrm{W}\right)$. Seeds of Q. muehlenbergii were collected from the Capitan Mountains of New Mexico (lat. $33^{\circ} 36^{\prime} 24^{\prime \prime N}$; long. $\left.105^{\circ} 21^{\prime} 47^{\prime \prime} \mathrm{W}\right)$. Two-year-old seedlings of $F$. velutina and 3 -year-old seedlings of $K$. paniculata (Sunland Nurseries, Mesilla, N.M.) (lat. 32 $18^{\prime} 42^{\prime \prime N}$; long. 106 $46^{\prime} 42^{\prime \prime W}$ ) were planted 13 Mar. 1999. All seedlings were grown individually in 3-L plastic pots filled with growing substrate (Sunshine no. 1, Sun Gro Hort., Bellevue, Wash.). This substrate contained Canadian sphagnum peat, perlite, vermiculite, major and minor nutrients, wetting agent, and dolomitic lime. Screens were placed at the bottom of the pots to retain the growing substrate. On 29 Mar. 1999, each plant received slow-release fertilizer(Osmocote; 14N-6.2P-11.6K; Scotts-Sierra Hort. Products, Marysville, Ohio) at a rate of $5 \mathrm{mg} \cdot \mathrm{cm}^{-3}$ substrate.

ENVIRONMENTAL CONDITIONS AND EXPERIMENTAL DESIGN. Plants were grown in a greenhouse located at New Mexico State University's Fabian Garcia Science Center (lat. 32¹6'48"N; long. $\left.106^{\circ} 45^{\prime} 18^{\prime \prime} \mathrm{W}\right)$. During the experimental period, mean daily midday photosynthetically active radiation $(P A R)$ as measured with a quantum sensor (LI-185; LICOR, Lincoln, Nebr.) was 663 $\pm 183 \mu \mathrm{mol} \cdot \mathrm{m}^{-2} \cdot \mathrm{s}^{-1}$. Air temperature and relative humidity $(\mathrm{RH})$ were measured with a combination temperature and humidity probe (model CS 500; Campbell Scientific, Logan, Utah). Day/ night greenhouse air temperatures averaged $23 / 18{ }^{\circ} \mathrm{C}$. Average daily $\mathrm{RH}$ was $88 \% \pm 6 \%$. Temperature of the growing substrate averaged $26 \pm 9{ }^{\circ} \mathrm{C}$ and was monitored $24 \mathrm{~h} \cdot \mathrm{d}^{-1}$ with a temperature probe (model 107; Campbell Scientific) inserted to a $6 \mathrm{~cm}$ depth into a pot. Probes were connected to a datalogger (CR10X; Campbell Scientific). Sensors were monitored every $5 \mathrm{~s}$ and averages of environmental data were logged every $5 \mathrm{~min}$. Before irrigation treatments started, each plant received $2.1 \mathrm{~L}$ of tap water [pH 7.5 and electrical conductivity $(\mathrm{EC})$ of $5.4 \mathrm{dS} \cdot \mathrm{m}^{-1}$ ] every other day.

On 6 June 1999, the 20 most uniform plants from each species were selected. Ten plants from each of seven species were assigned randomly to each of two irrigation treatments (drought and control). The experimental unit was a single seedling in a pot. The experimental design was a randomized complete block with 10 blocks, seven species, and two irrigation treatments.

INITIAL HARVEST. On 7 July 1999, irrigation treatments were initiated. On that day, two plants from each species in each of two treatments (two blocks) were selected randomly and harvested destructively to determine initial seedling growth characteristics. Surface area of leaves $\geq 3 \mathrm{~cm}$ long was measured with a leaf area meter (LI 3000A; LICOR). After leaf area was determined, plant height was recorded, and stems were severed $2.5 \mathrm{~cm}$ above the level of growing substrate and placed in paper bags. Xylem (young and mature) diameter was measured at $1 \mathrm{~cm}$ above the stem base after the bark was peeled back. Pots containing roots were stored at $4{ }^{\circ} \mathrm{C}$. Roots were washed free of growing substrate within $15 \mathrm{~d}$ of severance of stems. Weight of leaves, stems, and washed roots were determined after drying for $5 \mathrm{~d}$ at $70^{\circ} \mathrm{C}$. Eight blocks were retained to determine plant water relations during drought and plant morphological, anatomical, and developmental traits after exposure to drought.

Drought TREATMENT. At drought treatment initiation, all plants were irrigated to saturation. For each species, four of the eight plants assigned to drought were chosen randomly to indicate the end of a drought cycle. Indicator plants were allowed to drain for $1 \mathrm{~h}$ and then weighed. Subsequently, irrigation was withheld from plants receiving drought treatments. A drought cycle for each species ended when the combined weight of the their indicator pots decreased by $50 \%$ due to evapotranspiration (ET). We judged that this level of stress was severe enough to induce plant stress yet not cause plant death because preliminary experiments showed that $50 \%$ ET caused wilting but not mortality in three plant taxa(data not presented). Volumetric moisture content of the upper $6 \mathrm{~cm}$ of the growing substrate was determined at the end of each drought cycle with a theta probe (type HH1; Delta-T Devices, Cambridge, United Kingdom) set on the organic option. Volumetric water content at each drought cycle averaged $0.094 \pm$ $0.076 \mathrm{~m}^{3} \cdot \mathrm{m}^{-3}$ in drought plants and $0.352 \pm 0.097 \mathrm{~m}^{3} \cdot \mathrm{m}^{-3}$ in control plants. Control plants were irrigated to saturation every other day with an automatic drip irrigation system. During the experiment, emitter precipitation rate was adjusted so that there was minimal leaching from pots.

LEAF WATER RELATions. At the end of each drought cycle, irrigation was withheld until the following day. Then, predawn (0400 to $0500 \mathrm{HR}$ ) leaf water potential was determined on the youngest fully expanded leaf (Quercus L. sp.) or the terminal leaflet on all other plants by using a pressure chamber (PMS Instruments, Corvalis, Ore.). Because $F$. velutina and $K$. paniculata have odd-pinnately compound leaves, the terminal leaflet of these two taxa was selected for measurement of leaf water relations and all other subsequent foliar traits.

At midday (1130 to $1300 \mathrm{HR}$ ) of that same day, leaf water potential, stomatal conductance, and leaf transpiration were measured on all plants. For $F$. velutina and $K$. paniculata, midday measurements were taken on the terminal leaflet of the leaf opposite to the leaf selected for predawn measurements. For the Quercus sp., the leaf immediately basipetal to the leaf selected for predawn water potential was chosen for midday measurements. After measurements were taken, both drought and control plants were irrigated with a fertilizer solution $\left(\mathrm{pH} 6.7\right.$ and EC $1.3 \mathrm{dS} \cdot \mathrm{m}^{-}$ ${ }^{1}$ ) containing $\mathrm{N}$ at $10.7 \mathrm{mmol} \cdot \mathrm{m}^{-3}$ from a mixture of Peters Excel $(15 \mathrm{~N}-2.2 \mathrm{P}-12.5 \mathrm{~K})$, and Peters Professional (20N-4.4P-16.6K) fertilizer (Scotts-Sierra, Marysville, Ohio). Indicator pots were allowed to drain for $1 \mathrm{~h}$, reweighed, and the new weight was used as the initial value that determined the end of the next drought cycle.

Destructive harvest. All plants were harvested destructively 31 Oct. 1999, $116 \mathrm{~d}$ after the start of the drought treatment. The harvest date was selected so that it coincided with a day at the end of growing season when all plant taxa were in an uncompleted drought cycle. Because the length of a drought cycle varied among taxa, the period between completion of a species last drought cycle and its final harvest varied among taxa. Plant height, xylem diameter, total leaf surface area, and dry weight (DW) of leaves, stems and roots were determined using procedures described for the initial harvest. Specific leaf weight was calculated by dividing the DW of a $1-\mathrm{cm}^{2}$ disc by its area. Discs were excised from the same interveinal region on one fully expanded leaf from each plant, 3 to $6 \mathrm{~cm}$ from the apex of the leaf. Discs were dried at $70{ }^{\circ} \mathrm{C}$ for $5 \mathrm{~d}$.

Microscopy AND Histology. Three leaf discs were taken from one leaf in each of three plants in each treatment selected previously to determine specific leaf weight. Discs were adjacent to the one chosen for specific leaf weight determination. The first disc $\left(0.025 \mathrm{~cm}^{2}\right)$ was selected for light microscopy, the second disc $\left(0.17 \mathrm{~cm}^{2}\right)$ was used for scanning electron microscopy, and 
the third disc $\left(0.17 \mathrm{~cm}^{2}\right)$ was kept as a substitute if needed.

Discs selected for light microscopy were fixed in $3 \mathrm{~mL} 1 \mathrm{M}$ gluteraldehyde for $24 \mathrm{~h}$, rinsed three times with cacodylate buffer ( $\mathrm{pH}$ 7.2), then postfixed in osmium tetroxide for $2 \mathrm{~h}$. Samples were removed from osmium tetroxide, washed three times in the cacodylate buffer, and dehydrated in a graded series of ethanol, and then embedded in Spurr's epoxy resin (Spurr, 1969). Multiple $2 \mathrm{~mm}$ sections were cut, attached to uncoated slides and stained with epoxy tissue stain (Electron Microscopy Sciences, Fort Washington, Pa.). Leaf thickness was measured using a microscope (BH-2; Olympus Optical, Tokyo, Japan) fitted with an ocular micrometer. Two measurements, $0.25 \mathrm{~mm}$ apart, were taken on one randomly selected section.

The discs selected for scanning electron microscopy were fixed, postfixed, and dehydrated as was done for light microscopy. Dehydrated samples were critical-point dried with liquid carbon dioxide in a critical-point dryer (Ladd Research Industries, Burlington, Vt.) and sputter-coated with gold in a sputter coater (Desk II; Denton Vacuum, Moorestown, N.J.). Samples were then cut in half and each half was attached to an aluminum stub so that the abaxial and adaxial leaf surface could be viewed. Leaf surface morphology was examined with a scanning electron microscope (model S-3200; Hitachi Instruments, San Jose, Calif.) operating at $15 \mathrm{kV}$.

One fully expanded leaf from all plants was placed in a plastic bag and stored at $5{ }^{\circ} \mathrm{C}$ until stomatal impressions could be made. Impressions were made by applying clear fingernail polish (No. 61, Revlon, New York, N.Y.) to the abaxial surface of the leaf between 3 and $6 \mathrm{~cm}$ from the apex of the leaf and adjacent to the midvein. The matrix was allowed to dry for $15 \mathrm{~min}$, lifted with forceps and attached to a clean slide (St. Hilaire and Graves, 1999). Stomata within a $0.204 \mathrm{~mm}^{2}$ area were counted using a microscope (BH-2; Olympus). The number of abaxial stomata per square millimeter of leaf surface (stomatal density) then was calculated.

Another fully expanded leaf was selected, enclosed in a plastic bag, and stored at $5{ }^{\circ} \mathrm{C}$ until the number of abaxial trichomes (trichome density) could be assessed. Trichomes on the abaxial leaf surface were counted between 3 and $6 \mathrm{~cm}$ from the apex of the leaf, adjacent to the midvein by viewing a $0.96 \mathrm{~mm}^{2}$ area with a microscope (SZ60; Olympus). For each leaf, the number of trichomes within $10 \mathrm{~mm}^{2}$ was determined.

CUTICUlar wax CONTENT. Leaf cuticular wax was determined from the leaf used previously to assess trichome density. Leaves were submerged in three 1-min consecutive washes of $30 \mathrm{~mL}$ chloroform. The $90 \mathrm{~mL}$ of chloroform was filtered through filter paper (Whatman no. 541; Whatman, Maidstone, Kent, United Kingdom) to remove foliar debris and poured into a beaker of known weight. The chloroform was evaporated under a fume hood $\left(\approx 26{ }^{\circ} \mathrm{C}\right)$ for $36 \mathrm{~h}$ to leave the cuticular wax residue. Cuticular wax content was calculated as final beaker weight minus initial beaker weight divided by lamina surface area (Tipton and White, 1995).

Data ANALYSIS. Data were analyzed using SAS protocols (SAS Inst. Inc., Cary, N.C.). Means of biomass allocation, specific leaf weight, wax content, and parameters of leaf anatomy and morphology were separated using Fisher's least significant difference (LSD) at $P \leq 0.05$ after analysis of variance. The relationship of leaf water potentials and stomatal conductance with drought cycle (time) was analyzed using repeated measures in the GLM procedure of SAS (SAS Institute). Contrasts among drought cycles within taxa were analyzed by the GLM procedure. Comparisons were made among taxa between drought and controls and also within taxa between drought and control treatments. Means were separated using Fisher's LSD at $P \leq 0.05$. Net assimilation rate (NAR) was used to determine the efficiency of plants in accumulating dry matter. NAR was calculated by using the equation of Harper (1977): $N A R=M_{2}-M_{1} / T_{2}-T_{1} X \log L_{2}$ $-\log \mathrm{L}_{1} / \mathrm{L}_{2}-\mathrm{L}_{1}$, where $\mathrm{M}_{1}$ was the initial dry weight determined from four seedlings per species before irrigation treatment $\left(\mathrm{T}_{1}\right)$ was initiated, $M_{2}$ was plant DW at day $116\left(T_{2}\right)$, and $L_{2}$ and $L_{1}$ were the lamina surface area within species-treatment combinations at $\mathrm{T}_{2}$ and $\mathrm{T}_{1}$. Relative growth rate (RGR) was used to analyze the impact of irrigation treatment on plant growth. RGR was determined using the equation of Fisher (1921): $R G R=\ln W_{2}-\ln W_{1} /$ $\mathrm{T}_{2}-\mathrm{T}_{1}$, where $\mathrm{W}_{2}$ was the final dry weight at day $116\left(\mathrm{~T}_{2}\right)$ within species-treatment combinations, and $\mathrm{W}_{1}$ was the initial $\mathrm{DW}$ determined from four seedlings per species before irrigation treatment $\left(\mathrm{T}_{1}\right)$ was initiated.

\section{Results and Discussion}

Characterization of growth traits before drought began revealed that $F$. velutina had the greatest plant height while total leaf area ranged from $630 \mathrm{~cm}^{2}$ in $Q$. buckleyi to $6284 \mathrm{~cm}^{2}$ in $K$. paniculata (Table 1). Total leaf area to xylem diameter ratio reflects the balance between tissues that govern water loss, absorption, and transport (Zwack et al., 1998). This ratio differed

Table 1. Growth traits and biomass allocation patterns of the seven taxa harvested on the day irrigation treatments started (7 July 1999). Plants were harvested to determine initial seedling characteristics and to provide data to calculate NAR and RGR. Included are the number of drought cycles completed and the mean length of each drought cycle that plants completed at the end of $116 \mathrm{~d}$ of drought treatment.

\begin{tabular}{|c|c|c|c|c|c|c|c|}
\hline \multirow[b]{2}{*}{ Taxon } & \multirow{2}{*}{$\begin{array}{c}\text { Plant } \\
\text { ht } \\
(\mathrm{cm})\end{array}$} & \multirow{2}{*}{$\begin{array}{l}\text { Total } \\
\text { leaf } \\
\text { area } \\
\left(\mathrm{cm}^{2}\right)\end{array}$} & \multirow{2}{*}{$\begin{array}{c}\text { Leaf area/ } \\
\text { xylem } \\
\text { diam } \\
\left(\mathrm{cm}^{2} \cdot \mathrm{mm}^{-1}\right)\end{array}$} & \multirow{2}{*}{$\begin{array}{l}\text { Root } \\
\text { dry } \\
\text { wt } \\
(\mathrm{g})\end{array}$} & \multirow{2}{*}{$\begin{array}{c}\text { Root/ } \\
\text { shoot } \\
\text { DW }\end{array}$} & \multicolumn{2}{|c|}{$\begin{array}{l}\text { Drought cycles } \\
\text { completed }\end{array}$} \\
\hline & & & & & & No. & $\begin{array}{c}\text { Mean } \\
\text { length }(\mathrm{d})\end{array}$ \\
\hline$\overline{\text { Fraxinus velutina }}$ & $184 a^{z}$ & $4968 \mathrm{ab}$ & $469 \mathrm{ab}$ & $17 \mathrm{c}$ & $0.30 \mathrm{c}$ & 9 & 9 \\
\hline Koelreuteria paniculata & $138 \mathrm{~b}$ & $6284 \mathrm{a}$ & $420 \mathrm{ab}$ & $90 \mathrm{a}$ & $0.69 \mathrm{bc}$ & 6 & 13 \\
\hline Quercus buckleyi & $32 \mathrm{~d}$ & $630 \mathrm{c}$ & $140 \mathrm{~d}$ & $10 \mathrm{c}$ & $1.70 \mathrm{ab}$ & 1 & 58 \\
\hline Quercus lobata & $85 \mathrm{c}$ & $1993 \mathrm{c}$ & $279 c$ & $17 \mathrm{c}$ & $0.77 \mathrm{bc}$ & 4 & 29 \\
\hline Quercus macrocarpa & $76 \mathrm{c}$ & $4497 \mathrm{~b}$ & $488 \mathrm{a}$ & $46 b$ & $0.98 \mathrm{bc}$ & 5 & 17 \\
\hline Quercus muehlenbergii & $45 \mathrm{~d}$ & $2140 \mathrm{c}$ & $353 \mathrm{bc}$ & $8 \mathrm{c}$ & $0.60 \mathrm{bc}$ & 3 & 24 \\
\hline Quercus shurmardii & $30 \mathrm{~d}$ & $666 \mathrm{c}$ & $114 \mathrm{~d}$ & $7 \mathrm{c}$ & $2.31 \mathrm{a}$ & 1 & 65 \\
\hline$P$ value & 0.0001 & 0.0189 & 0.0001 & 0.0001 & 0.05 & --- & --- \\
\hline
\end{tabular}

${ }^{\mathrm{z}}$ Mean $(\mathrm{n}=4)$ separation within columns by Fisher's LSD at $P \leq 0.05$. 
among the seven plant taxa (Table 1). Root to shoot ratio was significantly different among species $(P=0.05)$. The relatively low root to shoot ratio (0.30) of $F$. velutina suggests this taxon may have limited capacity for absorption of water by the root system. If this early growth trait remains stable throughout ontogeny, then this limitation implies that the shoot may not maintain a well-hydrated condition when transpiration is high (Joly et al., 1989).

Differences in the rates of evapotranspiration caused the duration of a drought cycle, and hence, the number of drought cycles, to vary in each species (Table 1). There were differences in predawn water potential between drought-stressed and control plants only for $F$. velutina, K. paniculata, $Q$. macrocarpa, and $Q$. muehlenbergii (Fig. 1A, B, E, and F, respectively). In these taxa, control plants showed stable and near optimum predawn water potential (near $0 \mathrm{MPa}$ ), indicating that moisture was not limiting (Fig. 1A, B, E, and F). Predawn leaf water potential is an indicator of the energy level in the leaf before transpiration and photosynthesis commences (Abrams and Knapp, 1986), and may provide an estimate of the soil water potential (Hinckley et al., 1980). The
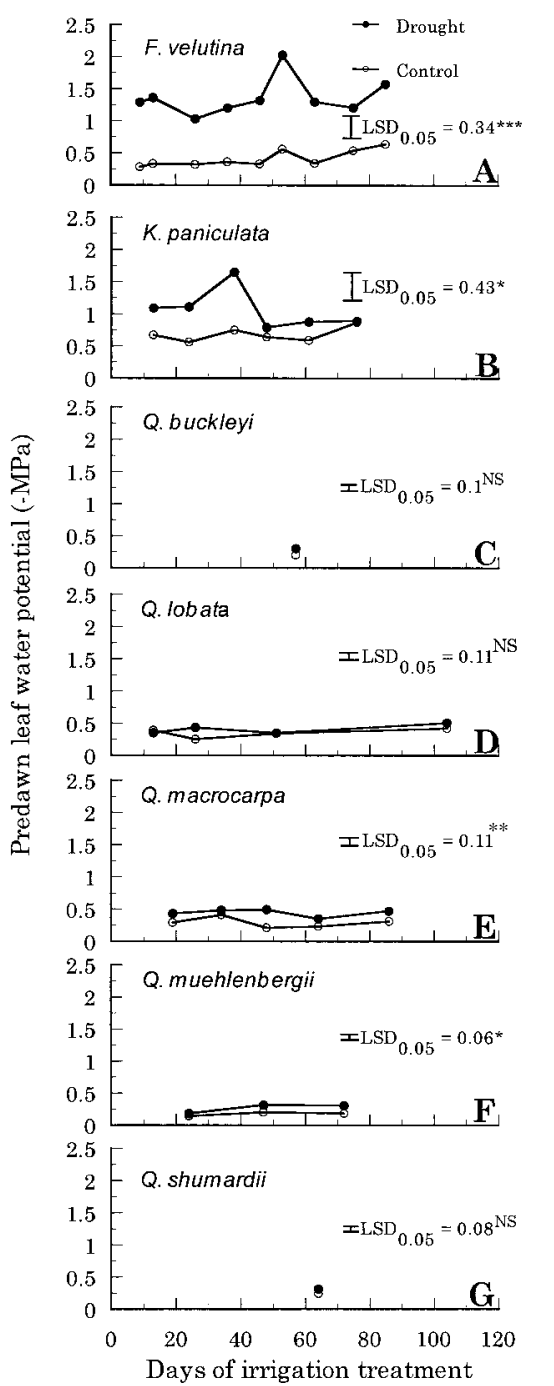

consistently low predawn water potential of drought-stressed leaves of $F$. velutina (Fig. 1A) suggests the leaves of this plant were not fully rehydrated at the end of each drought cycle.

After the third drought episode (48 d after the start of irrigation treatments), predawn water potential was similar for droughtstressed and control plants of $K$. paniculata (Fig. 1B), illustrating that drought-stressed plants recovered from internal water deficits during the dark period. At the second and fourth drought cycles, predawn water potentials of drought-stressed and control plants of $Q$. macrocarpa were the same (Fig. 1E). Predawn water potential of $Q$. muehlenbergii was statistically different only after the first drought cycle (Fig. 1F). Predawn water potential in drought-stressed plants of $Q$.macrocarpa

Fig. 1. Mean predawn leaf water potential of trees in drought or control treatments: (A) Fraxinus velutina, (B) Koelreuteria paniculata, (C) Quercus buckleyi, (D) Quercus lobata, $(\mathbf{E})$ Quercus macrocarpa, $(\mathbf{F})$ Quercus muehlenbergii, and $(\mathbf{G})$ Quercus shumardii. Legend in A applies to all figures and each symbol represents the end of a drought cycle and is the mean of eight observations. ns, ${ }^{* * *, * * *}$ Nonsignificant or significant at $P \leq 0.05,0.01$, or 0.001 , respectively.
(Fig. 1E) and Q. muehlenbergii (Fig. 1F) averaged -0.44 and $0.27 \mathrm{MPa}$, respectively. We found that the LSD among all species for predawn water potential was $-0.17 \mathrm{MPa}$. This suggests that the Quercus sp. used in this study were able to rehydrate their leaves better than either $F$. velutina or $K$. paniculata and would be advantageous in landscapes with a reduced moisture budget. Average predawn water potential of $Q$. lobata (Fig. 1D) was $0.39 \mathrm{MPa}$ and plants subjected to drought did not have more negative predawn water potentials than the controls. In $Q$. buckleyii (Fig. 1C) and Q. shurmardii (Fig. 1G), drought did not affect predawn water potential which averaged -0.24 and $-0.29 \mathrm{MPa}$, respectively.

Drought-stressed plants of $F$. velutina and $K$. paniculata had more negative midday water potentials than the control plants (Fig. 2A and B). In this study, midday leaf water potential of $F$. velutina and $K$. paniculata were as low as -2.9 and $-3.0 \mathrm{MPa}$, respectively, which illustrates the severity of the drought treatments imposed. This level of water deficit stress could be the lower limit of leaf dehydration in some woody species (Augé et al., 1998) or could curtail growth in several crop species (Hsiao, 1973). We are not aware of previously reported values for either midday or predawn water potential values for $F$. velutina and $K$. paniculata. In $Q$. lobata, there was a difference in midday water potential between control and drought-stressed plants after the first drought cycle (Fig. 2D). In $Q$. macrocarpa, drought-stressed plants had more negative midday water potential than controls only after the second drought cycle (Fig. 2E). Midday water potential averaged -0.75 , -0.71 , and $-0.84 \mathrm{MPa}$ in Q. buckleyii (Fig. 2C), $Q$. muehlenbergii (Fig. 2F), and $Q$. shurmardii (Fig. $2 \mathrm{G})$, respectively. In these three taxa, drought did not decrease midday water potential illustrating that plants in the drought-stress treatments remained relatively well hydrated

Stomatal conductance of $F$. velutina control plants ranged from 142 to $420 \mathrm{mmol} \cdot \mathrm{m}^{-2} \cdot \mathrm{s}^{-1}$, but

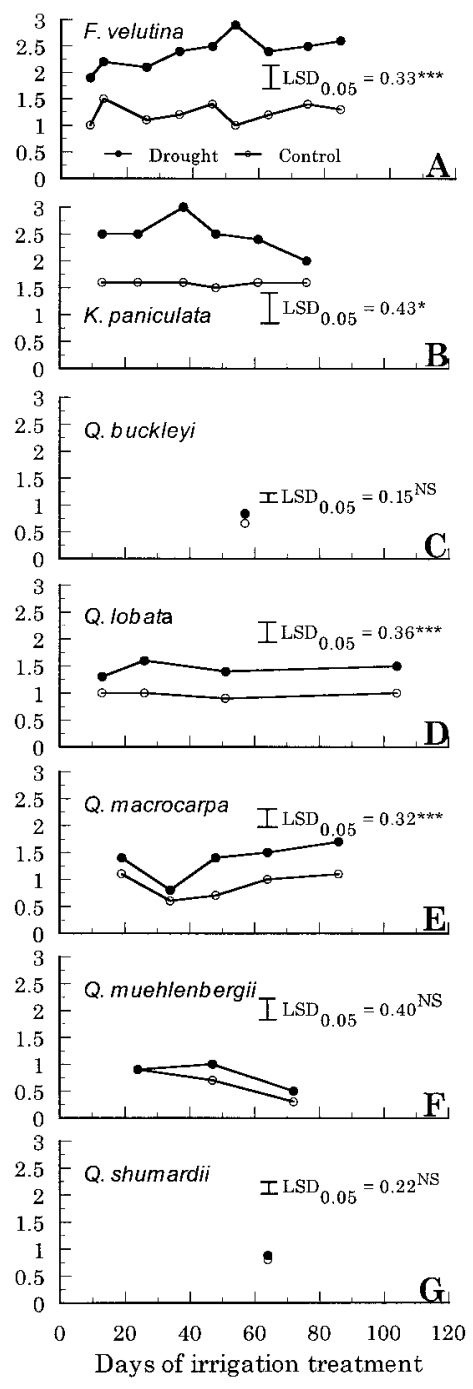

Fig. 2. Mean midday leaf water potential of trees in drought or control treatments (A) Fraxinus velutina, (B) Koelreuteria paniculata, (C) Quercus buckleyi, (D) Quercus lobata, (E) Quercus macrocarpa, (F) Quercus muehlenbergii, (G) Quercus shumardii. Legend in A applies to all figures and each symbol represents the end of a drought cycle and is the mean of eight observations. ns,,$* * * *$ Nonsignificant or significant at $P \leq 0.05$ or 0.001 , respectively. 
remained higher than that of drought-stressed plants (Fig. 3A). Stomatal conductance was similar for control and stressed plants of $K$. paniculata at the end of the sixth drought cycle (Fig. 3B). Drought treatment did not affect stomatal conductance of $Q$. buckleyi (Fig. 3C), Q. lobata (Fig. 3D), Q. muehlenbergii (Fig. 3F), and Q. shumardii (Fig. 3G). At the end of second, fourth, and fifth drought cycles, control and stressed plants of Q. macrocarpa had similar stomatal conductances (Fig. 3E). Drought reduced stomatal conductance to as little as $17 \%, 23 \%$, and $45 \%$ of controls in F. velutina, K. paniculata, and Q. macrocarpa, respectively. The high stomatal conductance of control plants of $F$. velutina would allow rapid carbon assimilation when moisture was abundant. While very little soil drying is required to initiate stomatal closure and the stomatal sensitivity of woody plants to drought varies with species (Croker et al., 1998), the severity of our drought treatments was sufficient to cause a severe reduction in stomatal conductance rates in those three plant taxa.

Transpiration rates in drought-stressed plants of $F$. velutina were less than that of control plants at every drought cycle (Fig. 4A). Drought may have reduced whole-plant conductivity (Brodribb and
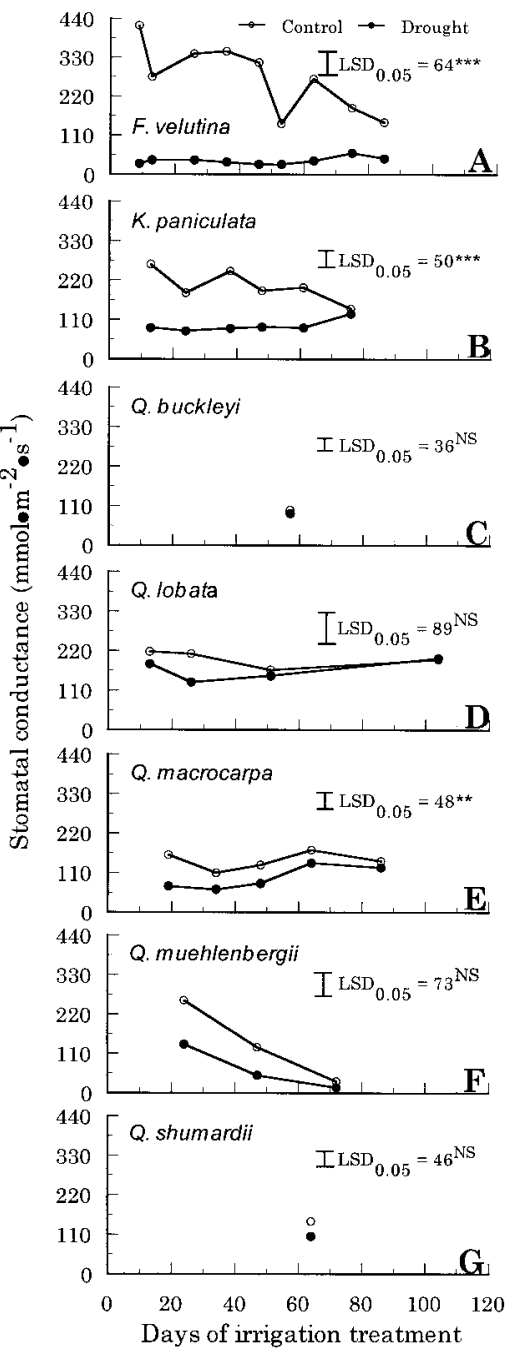

Hill, 2000), which would lead to curtailed transpiration rates. Irrigation treatment did not affect transpiration rates of $Q$. buckleyi, $Q$. lobata, $Q$. muehlenbergii, and $Q$. shumardii (Fig. 4C, D, F, and $\mathrm{G}$, respectively). Drought-stressed and control plants of $K$. paniculata, Q. macrocarpa, and $Q$. muehlenbergii had similar transpiration rates during their lastdrought cycle (Fig.4B, $\mathrm{E}$, and $\mathrm{F}$, respectively). One possible reason for the similarity in both stomatal conductance and rates of transpiration of those plants at the end of the last drought cycle is that they may have started to go dormant. At harvest, we observed that leaves of $Q$. shumardii had traces of fall foliage color.

NAR was different among taxa $(P=0.0001)$, but similar between irrigation treatments $(P=$ 0.4850) (Fig. 5A). Similarly, RGR was different among taxa $(P=0.0001)$, but similar for control and

Fig. 3. Stomatal conductance of trees in drought or control treatments: (A) Fraxinus velutina, (B) Koelreuteria paniculata, (C) Quercus buckleyi, (D) Quercus lobata,, E) Quercus macrocarpa,,$(\mathbf{F})$ Quercus muehlenbergii, and $(\mathbf{G})$ Quercus shumardii. Legend in A applies to all figures and each symbol represents the end of a drought cycle and is the mean of eight observations. ss, ${ }^{*}, * *, * * * *$ Nonsignificant or significant at $P \leq 0.01$ or 0.001 , respectively.

drought plants $(P=0.5125)$ (Fig. 5B). NAR and RGR were the highest in F. velutina (Fig. 5A and B), indicating this taxon accumulated dry matter faster and more efficiently relative to the other six taxa included in this study. Rapid and efficient growth could be an advantage for a landscape tree, especially if that growth is not severely curtailed by environmental factors, such as drought. Quercus shumardii had a negative NAR, indicating this plant did not grow.

Total leaf area and total leaf area to xylem diameter ratio were the largest in $F$. velutina. There was neither an irrigation effect nor a taxon by drought interaction (Table 2). The high total leaf area to xylem diameter ratio of $F$. velutina indicates there is a relatively large proportion of tissues that could potentially lose water or photosynthesize compared with tissues that govern water transport. Mean specific leaf weight, trichome density, stomatal density, leaf thickness, and wax content varied among species (Table 2). For these parameters, there was no irrigation effect or taxon by drought interaction. St. Hilaire and Graves (2001) found differences in specific leaf weight of Acer saccharum Marsh. (sugar maple) and Acer nigrum Michx.f. (black maple) while observing no differences between well-watered and drought-stressed plants. Because we found differences in specific leaf weight and total leaf thickness, but observed no correlation $(P=$ $0.6047)$ between these two foliar traits, we conclude that specific leaf weight varied because of differences in cell density or other factors such as chloroplast density (Kloeppel and Adams, 1995; St. Hilaire and Graves, 2001).

Leaves of $F$. velutina had 1836 trichomes $/ \mathrm{cm}^{2}$, and were the most pubescent of the taxa used in this study. Although the specific epithet velutina, refers to velutinous (velvety) hairs of the leaves (Vines, 1994), the pubescence of $F$. velutina had not been quantified previously. The occurrence of trichomes may slow leaf water loss by maintaining a larger leaf boundary layer and may be a strategy for reducing water loss from leaves (Johnson, 1975). Our data may represent the first quantitative comparison of pubescence of $F$. velutina with other woody plant
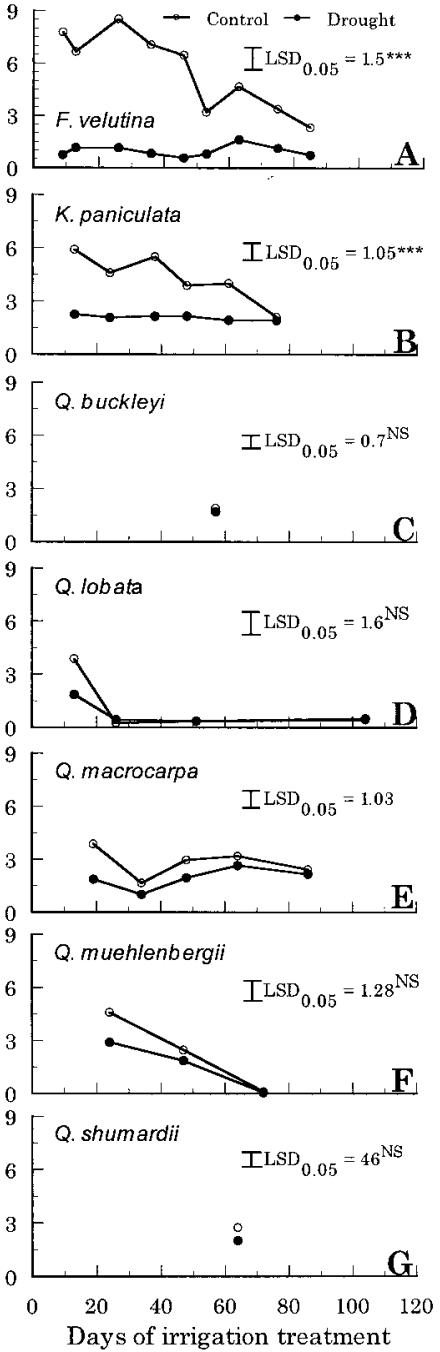

Fig. 4. Transpiration rates of trees in drought or control treatments: (A) Fraxinus velutina, (B) Koelreuteria paniculata, (C) Quercus buckleyi, (D) Quercus lobata, (E) Quercus macrocarpa, (F) Quercus muehlenbergii, and (G) Quercus shumardii. Legend in A applies to all figures and each symbol represents the end of a drought cycle and is the mean of eight observations. ${ }^{\mathrm{Ns},{ }^{* * * *} \text { Nonsignificant or }}$ significant at $P \leq 0.001$, respectively. 

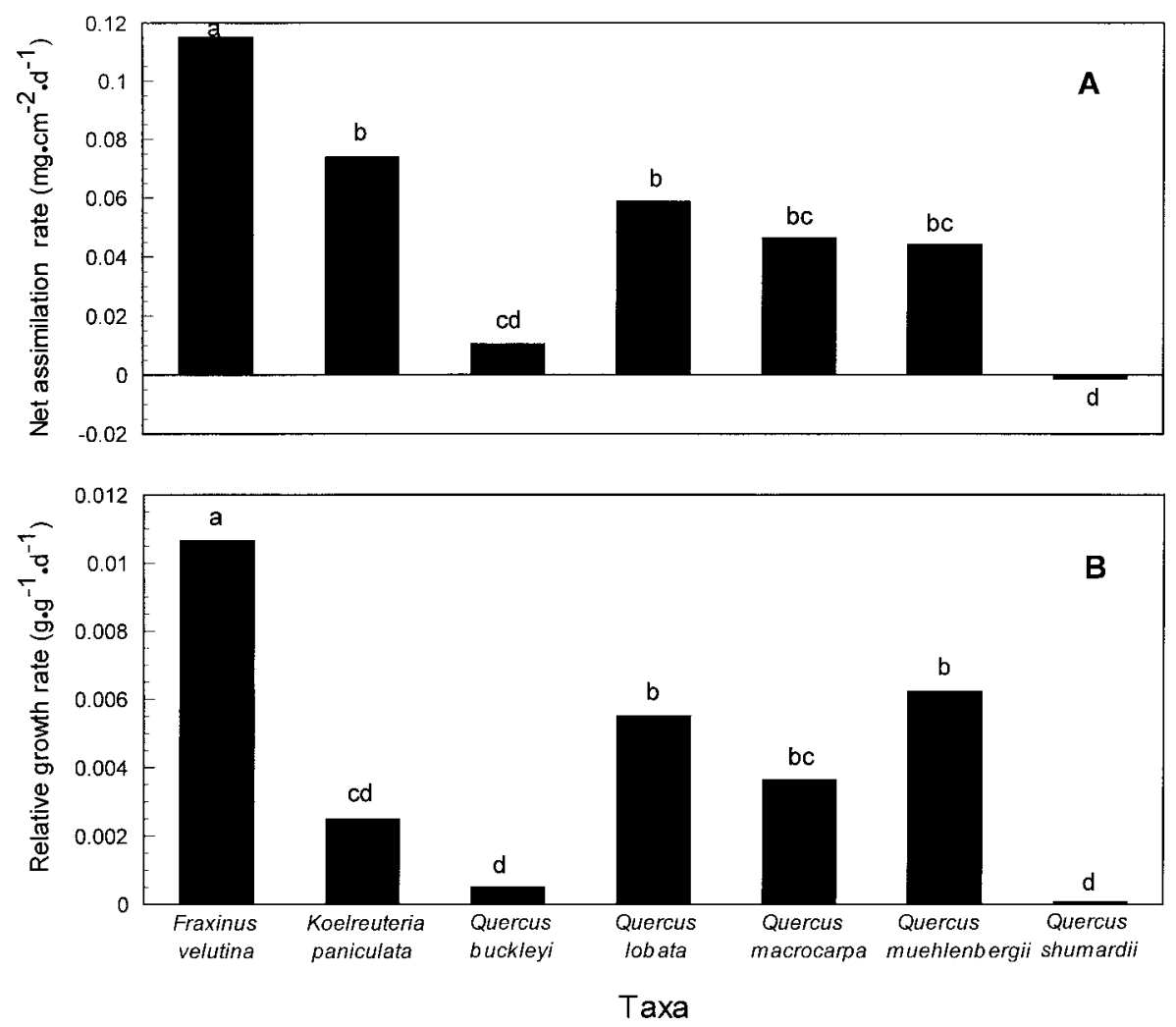

et al., 1997; Higgs and Wood, 1995). The relatively low stomatal densities of $F$. velutina and $K$. paniculata suggest that both species might be more adapted to mesic conditions (Donselman and Flint, 1982). Transpiration and stomatal conductance data suggest the stomata of $F$. velutina are sensitive to drought. This capability would allow plants of $F$. velutina to optimize carbon fixation in favorable environments and to limit water loss when water deficit stress is present. This might be true for $F$. velutina because NAR and RGR were the highest of all the taxa tested.

Quercus macrocarpa had one of the lowest epicuticular wax contents (Table 2), but scanning electron microscopy revealed marked differences in epicuticular wax architecture among taxa (Fig. 6A-F). The link between wax architecture and leaf water relations is not well understood. However, Tipton and White (1995) suggested that high epicuticular wax content may represent an effective drought tolerance mechanism because it could reduce light transmission and therefore heat accumulation, which might influence plant water relations. Because cuticular wax is a trait associated with

Fig. 5. (A) Net assimilation rate and (B) relative growth rate of trees after $116 \mathrm{~d}$ of irrigation treatment. There were no differences due to irrigation treatment. Data were pooled over irrigation treatments and each value represents the mean of 16 observations. Bars with different letters differ at $P \leq 0.05$ by Fisher's LSD.

taxa. Among the Quercus sp., Q. muehlenbergii was the most pubescent, while $Q$. buckleyii, and $Q$. shurmardii had relatively glabrous leaves (Table 2).

All the Quercus sp. used in this study had more stomata per area of abaxial leaf surface than either F. velutina or K. paniculata. High stomatal density has been associated with plants adapted to xeric environments (Donselman and Flint, 1982; St. Hilaire and Graves, 1999). This trait imparts better control of water loss (Fort plants adapted to arid environments (Tipton and White, 1995), the relatively high wax content of $F$. velutina, $K$. paniculata, and $Q$. buckleyi might reflect an adaptive advantage of those plants when they are grown in arid habitats.

Leaf surface area to root DW, leaf DW to root DW, shoot DW, and the root to shoot DW were different among species and between irrigation treatments (Table 3). Drought led to lower ratios of leaf area to root DW than controls. Zwack et al. (1998) found a similar trend in Acer $\times$ freemanii E. Murray (Freeman maple) subjected to drought and concluded that drought produced a more conservative balance between transpiring tissues and those that absorb moisture. Averaged over all species, control plants had $23 \%$ more leaf DW per gram of dry roots and $24 \%$ more

Table 2. Total leaf area, total leaf area : xylem diameter ratio, specific leaf weight, number of abaxial trichomes and stomates, leaf thickness, and cuticular wax content of seven taxa of plants exposed to $116 \mathrm{~d}$ of cyclic drought. There were no differences due to irrigation treatment. Values are means of 16 replications except for leaf thickness where values are the means of six replications.

\begin{tabular}{|c|c|c|c|c|c|c|c|}
\hline \multirow[b]{3}{*}{ Taxon } & \multirow{3}{*}{$\begin{array}{l}\text { Total } \\
\text { leaf } \\
\text { area } \\
\left(\mathrm{cm}^{2}\right)\end{array}$} & \multirow{3}{*}{$\begin{array}{c}\text { Total } \\
\text { leaf } \\
\text { area/ } \\
\text { xylem } \\
\text { diam } \\
\text { ratio } \\
\left(\mathrm{cm}^{2} \cdot \mathrm{mm}^{-1}\right)\end{array}$} & \multirow{3}{*}{$\begin{array}{c}\text { Specific } \\
\text { leaf } \\
w t \\
\left(\mathrm{mg} \cdot \mathrm{cm}^{-2}\right)\end{array}$} & & & \multicolumn{2}{|c|}{ Leaf } \\
\hline & & & & \multicolumn{2}{|c|}{ No. of abaxial } & Thickness & $\begin{array}{c}\text { Wax } \\
\text { content }\end{array}$ \\
\hline & & & & Trichomes $/ \mathrm{cm}^{2}$ & Stomates $/ \mathrm{mm}^{2}$ & $(\mathrm{~mm})$ & $\left(\mathrm{mg} \cdot \mathrm{cm}^{-2}\right)$ \\
\hline Fraxinus velutina & $8204 a^{2}$ & $474 \mathrm{a}$ & $7.7 \mathrm{a}$ & $1836 \mathrm{a}$ & $142 \mathrm{~d}$ & $188 \mathrm{a}$ & $202 \mathrm{a}$ \\
\hline Koelreuteria paniculata & $2916 \mathrm{c}$ & $174 \mathrm{c}$ & $6.3 \mathrm{bcd}$ & $89 \mathrm{~d}$ & $125 \mathrm{~d}$ & $188 \mathrm{a}$ & $115 \mathrm{bc}$ \\
\hline Quercus buckleyi & $442 \mathrm{~d}$ & $92 \mathrm{~d}$ & $7.3 \mathrm{ab}$ & $18 \mathrm{c}$ & $465 \mathrm{a}$ & $139 \mathrm{~b}$ & $166 \mathrm{ab}$ \\
\hline Quercus lobata & $2944 \mathrm{c}$ & $280 \mathrm{~b}$ & $7.2 \mathrm{abc}$ & $658 \mathrm{c}$ & $238 \mathrm{c}$ & $145 \mathrm{~b}$ & $110 \mathrm{bc}$ \\
\hline Quercus macrocarpa & $6020 \mathrm{~b}$ & $511 \mathrm{a}$ & $6.0 \mathrm{~cd}$ & $465 \mathrm{c}$ & $466 \mathrm{a}$ & $104 \mathrm{c}$ & $82 \mathrm{c}$ \\
\hline Quercus muehlenbergii & $2645 c$ & $329 \mathrm{~b}$ & $5.5 \mathrm{~d}$ & $1186 \mathrm{~b}$ & $460 \mathrm{a}$ & $127 \mathrm{bc}$ & $110 \mathrm{bc}$ \\
\hline Quercus shurmardii & $615 \mathrm{~d}$ & $108 \mathrm{~cd}$ & $7.4 \mathrm{ab}$ & $13 \mathrm{~d}$ & $398 \mathrm{~b}$ & $147 \mathrm{~b}$ & $238 \mathrm{a}$ \\
\hline$P$ value & 0.0001 & 0.0001 & 0.008 & 0.0001 & 0.0001 & 0.0001 & 0.0011 \\
\hline
\end{tabular}

${ }^{\mathrm{z}}$ Mean separation within columns by Fisher's LSD at $P \leq 0.05$. 

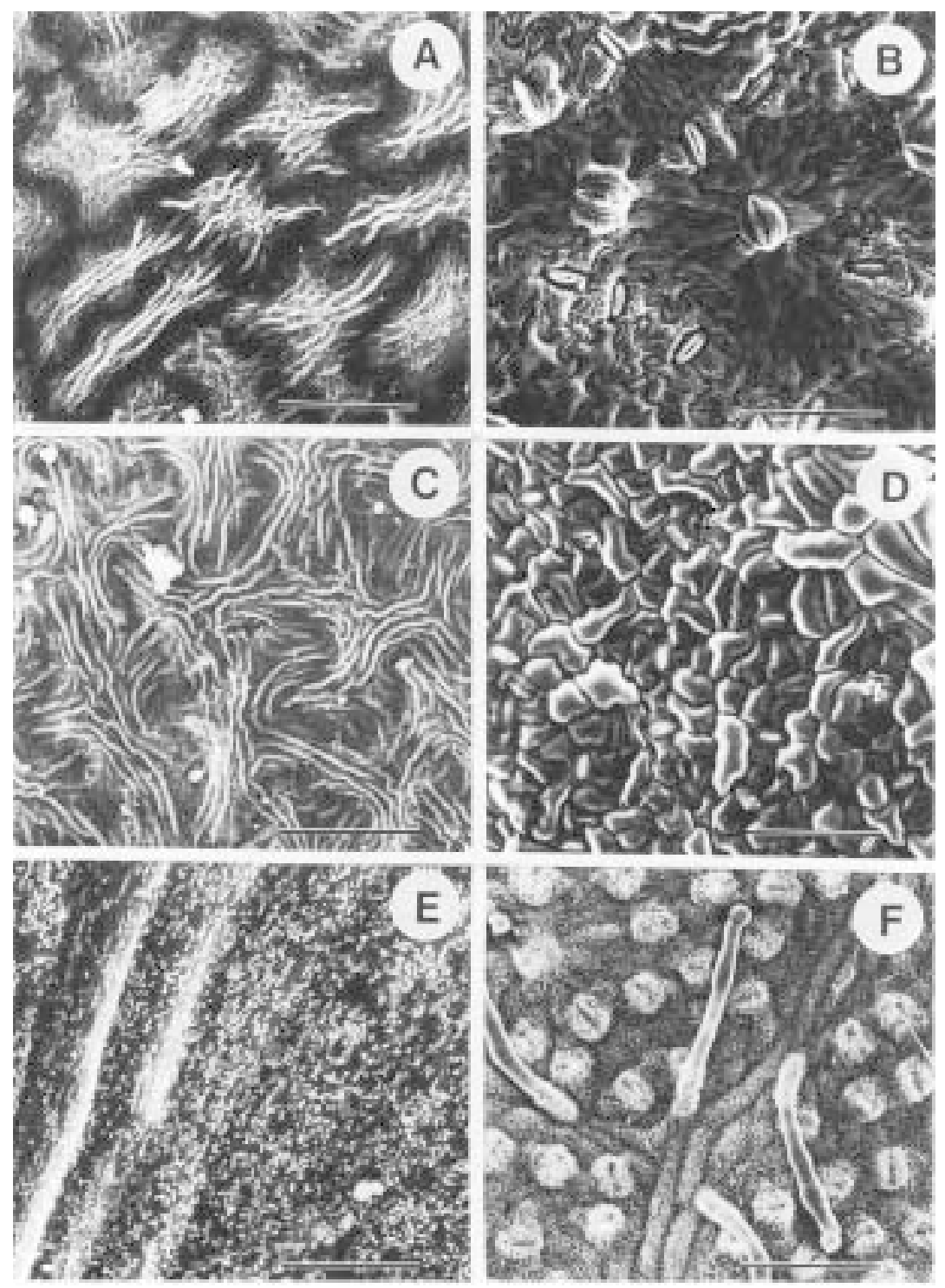

Fig. 6. Exemplar scanning electron micrographs of the adaxial and abaxial foliar surfaces of trees investigated in this study: (A) adaxial $($ bar $=25 \mu \mathrm{m})$ and $(\mathbf{B})$ abaxial $($ bar $=50 \mu \mathrm{m})$ foliar surface of Fraxinus velutina showing fissured layers of wax, (C) adaxial (bar $=25 \mu \mathrm{m}$ ) foliar surface of Koelreuteria paniculata showing fissured layers of wax, (D) abaxial (bar $=50 \mu \mathrm{m}$ ) foliar surface of K. paniculata showing smooth layers of wax, $(\mathbf{E})$ adaxial (bar = $25 \mu \mathrm{m}$ ) foliar surface of Quercus macrocarpa showing parallel plates of wax, and $(\mathbf{F})$ abaxial $($ bar $=25 \mu \mathrm{m})$ foliar surface of $Q$. macrocarpa showing granules of wax. Wax classifications are from Barthlott et al. (1998).

shoot DW than drought-stressed plants (Table 3), indicating that drought reduced foliar dry matter accumulation.

In many plant species, drought decreases root growth less than shoot growth (Prevete et al., 2000; St. Hilaire and Graves, 2001). Five of the seven taxa tested had more dry matter partitioned into roots than shoots, and averaged over all taxa, drought increased root growth more than shoot growth (Table 3 ). The magnitude of the quantity of dry matter allocated to roots rather than to shoots in Q. buckleyi (over three times) may represent a significant mechanism of stress avoidance. A higher root to shoot ratio means that the proportion of the total mass that could potentially explore the root zone for moisture is increased.

In summary, plant water relations and biomass allocation patterns were most impacted by the water deficit stress imposed. Plants of $F$. velutina exposed to drought had high predawn and midday leaf water potentials, reduced stomatal conductance, and low root to shoot DW ratio, all traits of plants adapted to mesic environments. However, NAR and RGR suggest that growth of this species was not reduced severely by conditions of drought imposed. Pubescence, thick, dense, and waxy leaves of $F$. velutina could mitigate the impact of drought. Thus, $F$. velutina might be suitable for managed landscapes that require a moderately fast-growing tree and are

Table 3. Leaf area to root dry weight, leaf to root dry weight, shoot DW, and root to shoot DW ratios for seven plant taxa subjected to $116 \mathrm{~d}$ of cyclic drought.

\begin{tabular}{|c|c|c|c|c|}
\hline $\begin{array}{l}\text { Dependent } \\
\text { variable }\end{array}$ & $\begin{array}{l}\text { Leaf area/ } \\
\text { root dry wt } \\
\left(\mathrm{cm}^{2} \cdot \mathrm{g}^{-1}\right)\end{array}$ & $\begin{array}{c}\text { Leaf/root } \\
\text { dry wt }\end{array}$ & $\begin{array}{l}\text { Shoot } \\
\text { dry wt } \\
\text { (g) }\end{array}$ & $\begin{array}{c}\text { Root/shoot } \\
\text { dry wt }\end{array}$ \\
\hline Fraxinus velutina & $103 \mathrm{a}^{\mathrm{z}}$ & $0.72 \mathrm{a}$ & $186.0 \mathrm{a}$ & $0.47 \mathrm{~d}$ \\
\hline Koelreuteria paniculata & $16 \mathrm{c}$ & $0.10 \mathrm{c}$ & $120.0 \mathrm{~b}$ & $1.78 \mathrm{~b}$ \\
\hline Quercus buckleyi & $32 \mathrm{c}$ & $0.15 \mathrm{c}$ & $5.4 \mathrm{c}$ & 3.13 \\
\hline Quercus lobata & $111 \mathrm{a}$ & $0.69 \mathrm{a}$ & $50.3 \mathrm{c}$ & 0.63 \\
\hline Quercus macrocarpa & $66 \mathrm{~b}$ & $0.28 \mathrm{~b}$ & $68.2 \mathrm{c}$ & 1.45 \\
\hline Quercus muehlenbergii & $101 \mathrm{a}$ & $0.39 \mathrm{~b}$ & $27.1 \mathrm{~d}$ & $1.11 \mathrm{c}$ \\
\hline Quercus shurmardii & $76 \mathrm{~b}$ & $0.34 \mathrm{~b}$ & $6.8 \mathrm{c}$ & $1.76 \mathrm{~b}$ \\
\hline \multicolumn{5}{|l|}{ Irrigation treatment } \\
\hline Control & $81 \mathrm{a}$ & $0.42 \mathrm{a}$ & $73.4 \mathrm{a}$ & $1.23 \mathrm{a}$ \\
\hline Drought & $63 \mathrm{~b}$ & $0.34 \mathrm{~b}$ & 59.1 & $1.73 \mathrm{~b}$ \\
\hline Significance & \multicolumn{4}{|c|}{$P$ values } \\
\hline Irrigation treatment & 0.0010 & 0.0153 & 0.0085 & 0.0001 \\
\hline Species & 0.0001 & 0.0001 & 0.0001 & 0.0001 \\
\hline Species $\times$ irrigation treatment & 0.3418 & 0.5282 & 0.2950 & 0.6162 \\
\hline
\end{tabular}

${ }^{\mathrm{z}}$ Mean separation within columns among species $(\mathrm{n}=16)$ and between irrigation treatments $(\mathrm{n}=56)$ by Fisher's LSD at $P \leq 0.05$. 
subjected to moderate drought. Data herein suggest that $Q$. buckleyi might be a plant worth trying in xeriscapes because of the lack of the impact of drought on tissue water relations, high stomatal density, waxy leaves, and a large root system relative to the shoots. Although drought-stressed plants of $Q$. lobata and $Q$. macrocarpa sustained lower midday leaf water potentials than either $F$. velutina and $K$. paniculata, the low investment of these plants in roots could render them susceptible to drought during periods of high evaporative demand. Quercus muehlenbergii and $Q$. shumardii tended to display traits of plant adapted to xeric environments. Evaluation of drought responses of these two species in an arid environment warrants further research.

\section{Literature Cited}

Abrams, M.D. and A.K. Knapp. 1986. Seasonal water relations of three gallery forest hardwood species in northeast Kansas. For. Sci. 32:687696.

Augé, R.M., D. Xiangrong, J.L. Croker, W.T. Witte, and C.D. Green. 1998. Foliar dehydration tolerance of twelve deciduous tree species. J. Expt. Bot. 49:753-759.

Barthlott, W., C. Neinhuis, D. Cutler, F.Ditsch, I. Meusel, I. Theisen, and H. Wilhelm. 1998. Classification and terminology of plant epicuticular waxes. Bot. J. Linnean Soc. 126:237-260.

Brodribb, T.J. and R.S. Hill. 2000. Increases in water potential gradient reduce xylem conductivity in whole plants. Evidence from a lowpressure conductivity method. Plant Physiol. 123:1021-1028.

Croker, J.L., W.T. Witte, and R.M. Augé. 1998. Stomatal sensitivity of six temperate, deciduous tree species to non-hydraulic root-to-shoot signaling of partial soil drying. J. Expt. Bot. 321:761-774.

Devitt, D.G., J.R. Simpson, and J.L. Tipton. 1995. Water use of two landscape tree species in Tucson, Arizona. J. Amer. Soc. Hort. Sci. 120:409-416.

Donselman, H.M. and H.L. Flint. 1982. Genecology of eastern redbud (Cercis canadensis). Ecology 63:962-971.

Feldman, W.R., S.A. Carter, and K.W. Stone. 1997. Water requirements of arid-adapted groundcover and sub-shrub species for landscape use in Arizona. Desert Plants 13:18-24.

Fisher, R.A. 1921. Some remarks on the methods formulated in a recent article on the quantitative analysis of plant growth. Ann. Appl. Biol. 7:367.

Fort, C., M.L. Fauveau, F. Muller, P. Pabel, A. Granier, and E. Dreyer. 1997. Stomatal conductance, growth and root signaling in young oak seedlings subjected to partial soil drying. Tree Physiol. 17:281-289.

Graves, W.R. and L.C. Wilkins. 1991. Growth of honey locust seedlings during high root-zone temperature and osmotic stress. HortScience 26:1312-1315.

Hamerlynck, E.P. and A.K. Knapp. 1996. Early season cuticular conductance and gas exchange in two oaks near the western edge of their range. Trees 10:403-409.

Harper, J.L. 1977. Population biology of plants. Academic, London.

Higgs, K.H. and V. Wood. 1995. Drought susceptibility and xylem dysfunction in seedlings of four European oak species. Ann. Sci. For. 52:507-513.

Hinckley, T.M., F. Duhme, A.R. Hinckley, and H. Richter. 1980. Water relations of drought hardy shrubs: Osmotic potential and stomatal reactivity. Plant, Cell Environ. 3:131-140.
Hsiao, T.C. 1973. Plant responses to water stress. Annu. Rev. Plant Physiol. 24:519-570.

Johnson, H.B. 1975. Plant pubescence: An ecological perspective. Bot. Rev. 41:233-258.

Joly, R.J., W.T. Adams, and S.G. Stafford. 1989. Phenological and morphological responses of mesic and dry site sources of coastal Douglas-fir to water deficit. For. Sci. 35:987-1005.

Kloeppel, B.D. and M.D. Adams. 1995. Ecophysiological attributes of the native Acer saccharum and exotic Acer platanoides in urban oak forests in Pennsylvania, USA. Tree Physiol. 15:739-746.

Kriedman, P.E. 1986. Stomatal and photosynthetic limitations to leaf growth. Austral. J. Plant Physiol. 13:15-31.

Kubiske, M.E., M.D. Abrams, and S.A. Mosstoller. 1996. Stomatal and nonstomatal limitations of photosynthesis in relation to the drought and shade tolerance of tree species in open and understory environments. Trees 11:76-82.

Levitt, D.G., J.R. Simpson, and J.L. Tipton. 1995. Water use of two landscape species in Tuscon, Arizona. J. Amer. Soc. Hort. Sci. 120:409416.

Nash, L.J. and W.R. Graves. 1993. Drought and flood stress effects on plant development and leaf water relations of five trees native to bottomland habitats. J. Amer. Soc. Hort. Sci. 118:845-850.

Post-Beittenmiller, D. 1996. Biochemistry and molecular biology of wax production in plants. Annu. Rev. Plant Physiol. Plant Mol. Biol. 47:405-430.

Prevete, K.J., R.T. Fernandez, and W.B. Miller. 2000. Drought responses of three ornamental perennials. J. Amer. Soc. Hort. Sci. 125:310-317.

Riederer, M. and G. Schneider. 1990. The effect of the environment on the permeability and composition of citrus leaf cuticles. II. Composition of soluble cuticular lipids and correlation with transport properties. Planta 180:154-166.

Roden, J., E. Van Volkenburgh, and T.M. Hinckley. 1990. Cellular basis for limitation of poplar leaf growth by water deficit. Tree Physiol. 6:211-219.

Schuepp, P.H. 1993. Leaf boundary layers. New Phytol. 125:477-507. Smith, C.S. and R. St. Hilaire. 1999. Xeriscaping in the urban environment. New Mexico J. Sci. 38:241-250.

Spurr, A.R. 1969. A low viscosity epoxy resin embedding medium for electron microscopy. Ultrastruct. Res. 26:31-43.

St. Hilaire, R. and W.R. Graves. 1999. Foliar traits of sugar maples and black maples near $43^{\circ} \mathrm{N}$ latitude in the eastern and central United States. J. Amer. Soc. Hort. Sci. 123:605-611.

St. Hilaire, R. and W.R. Graves. 2001. Stability of provenance differences during development of hard maple seedlings irrigated at two frequencies. HortScience 36:654-657.

Tipton, J.L. 1994. Relative drought resistance among selected southwestern landscape plants. J. Arboricult. 20:150-155.

Tipton, J.L. and M. White. 1995. Differences in leaf cuticle structure and efficacy among eastern redbud and mexican redbud phenotypes. J. Amer. Soc. Hort. Sci. 120:59-64.

Vines, R.A. 1994. Trees, shrubs, and woody vines of the southwest. Univ. Texas Press, Austin.

Whitlow, T.H. and N.L. Bassuk. 1988. Ecophysiology of urban trees and their management-The North American experience. HortScience. 23:542-546.

Zwack, J.A., W.R. Graves, and A.M. Townsend. 1998. Leaf water relations and plant development of three Freeman maple cultivars subjected to drought. J. Amer. Soc. Hort. Sci. 123:371-37. 